\title{
Establishment of Plaintiff Qualification of Administrative Public Interest Litigation in China
}

\author{
Weijun $\mathrm{Wu}$ \\ University of Electronic Science and Technology of China \\ Chengdu, China
}

\begin{abstract}
The public interest urgently needs guarantee of judicial remedy for it is often infringed upon in real life. With the establishment of the public interest litigation system in domestic civil field, the voice requiring for establishment of administrative public interest litigation system is louder and louder. And for this question, the first matter that needs to be settled is the plaintiff qualification, because it is the precondition for initiating administrative public interest litigation. Therefore, the plaintiff qualification is vital for establishing the litigation system of administrative public interest. In this paper, the theoretical basis of plaintiff qualification establishment of administrative public interest litigation is collected and sorted, and combining with the current legislation status and judicial practice in China, the establishing of plaintiff qualification of administrative public interest litigation is mainly discussed. And based on the above, it is proposed that, in China, the diversified model of plaintiff subject qualification containing procuratorial authority, social organizations and individual citizens shall be established. Besides, based on the diversified subjects of plaintiff qualification, it is recommended that the priority of the subjects shall be established while prosecuting litigation.
\end{abstract}

Keywords-administrative public interest litigation; plaintiff qualification; public interest

\section{INTRODUCTION}

The 2012 Amendment to Civil Litigation Law makes clear requirement on public interest litigation in the form of law for the very first time. This opens the door of civil public interest litigation in China. Article 55 of the Civil Litigation Law requires that: "For acts harming the social public interests, including the environment pollution and act harming the legal rights of numerous customers, the authorities and relative organizations required by the law may prosecute to the people's court." Though the above article is rough, the public interest litigation system has been established in basic law level in China. From then on, the administrative public interest litigation will sure be included into the items for adding. And the plaintiff qualification of administrative public interest litigation shall be established in legislative level.

\section{The MEANING of Plaintiff QUALIFICATION IN ADMINISTRATIVE PUBLIC INTEREST LITIGATION}

The plaintiff qualification in administrative public interest litigation is the core of administrative public interest

\author{
Qian Tan \\ University of Electronic Science and Technology of China \\ Chengdu, China
}

litigation. Its development will sure promote the development of administrative public interest litigation system. Therefore, the standard setting of plaintiff qualification recognition is vital for the establishing of the administrative public interest litigation system in real meaning. The plaintiff qualification of administrative public interest litigation can be summarized as: the subject conditions required by the laws to propose administrative litigation in its own name in order to protect public interest. Simply, it refers to the conditions or identities required for the person who can propose administrative public interest litigation. The purpose of identifying the plaintiff qualification is to "prevent random appeal, correctly execute the functions of judicial verification, thus to make the judicial verification the tool to solve dispute, guarantee legal performance of executive rights of administrative authorities, and respect individual rights, and not become the obstacle of administration.” [1]

\section{THEORETICAL BASIS FOR ESTABLISHING THE PLAINTIFF QUALIFICATION IN ADMINISTRATIVE PUBLIC INTEREST LITIGATION}

\section{A. Power Restriction Theory}

"The person who has authority is easy to abuse power. This is an eternal and immutable experience for ages. Men with power will never stop until encountering boundary. Speaking from the nature of the substance, the only way to prevent abuse power is to restrict by power." [2] The socalled power restriction theory is to separate the state powers into three parts: legislative power, executive branch, and judicial branch. The three shall be separate and restrictive to each other. Since the 20th century, the executive branch has rapidly expanded. The potential risk of executive right abuse has becoming more and more serious. The power restriction has been reaffirmed repeatedly. The restriction of judicial branch to executive branch becomes vital. One of the purposes to establish the administrative public interest litigation system is to supervise the executive rights. It is the important composing part of the big mesh restricting the abuse of executive rights.

\section{B. Public Trust Theory}

"Public trust" theory is derived from Roman law, referring to: air, stream, coast, and wasteland, are all the common property of mankind and held by the King or the 
government in forma of public trust for the purpose of public interests and public use. [3] The government is entrusted by the nationals to manage the public properties. It shall be responsible for protecting these properties from being damaged, and shall not randomly dispose these properties without the authorization of the nationals. The application of the public trust in litigation law develops the theory of litigation trust. This means that, the nationals make the public properties be managed by the government via trust, and meanwhile, the nationals also entrust part of their own litigation right for these properties to the nation. Therefore, when any of these properties are infringed, the government shall be responsible for protecting the trusted properties. However, the government is made up by state organs. And this litigation right is assigned to specific state organ or related organization. If this state organ or related organization fails to prosecute to the court, any national may prosecute public interest litigation to the court in his/her own name according to the public trust. And based on the public trust theory, the procuratorial organ may, on behalf of the people, act the litigation right for protecting the public properties, which was original entrusted to the state by the nationals, to become the plaintiff in the administrative public interest litigation.

\section{Theory of Extension of Litigation Interest}

There's a saying in the Anglo-American legal system countries "No interest, no right to appeal". That means the person who appeals to seek for legal remedy must have the interest under protection of law. This is also the precondition for the case entering litigation procedure. Under the traditional principle of "interest of litigation", the plaintiff in administrative litigation must seek for judicial remedy only for its own rights or legal interest. And the law is to balance according to the stake to see whether the individual interest could be applicable for judicial remedy or not, thus to not only make common private interest be protected by litigation, but also prevent random appeal with no interest relation. However, the way of balancing whether the "interest of litigation" available or not only by stake may make the public interest lack of right to appeal when it suffers infringement. In China, the civil litigation has endowed the right to appeal for "environment pollution, infringement to social public interest, including infringement to numerous consumers' legal rights" to authorities and organizations required by law. In China, the interest of litigation of plaintiff in civil litigation has been extended from the individual interest to social public interest, which shall also be applicable for administrative litigation. Therefore, for the illegal administrative act harming public interest, certain type of subject shall be given with the right to prosecute according to wider interest demands.

\section{ESTABLISHMENT OF PLAINTIFF QUALIFICATION SYSTEM OF ADMINISTRATIVE PUBLIC INTEREST LITIGATION IN CHINA}

\section{A. Establishment of Plaintiff Subject Qualification of the Procuratorate for Administrative Public Interest Litigation}

Firstly, as the legal supervisory authority, the people's procuratorate shall supervise the execution and implementation of the national laws. The unique legal status and nature of the people's procuratorate make it qualified as the plaintiff of the administrative public interest litigation. Article 10 of Administrative Litigation Law requires that, the people's procuratorate shall have the right to perform legal supervision on the execution of the Administrative Litigation Law. "As the judicial authority, the people's court ranks the judge status and cannot perform the right to prosecute. And the People's Congress and the standing committees cannot have the rights of both legislation and prosecution due to its nature as state organs, because this goes against the modern concept of governance by law. Therefore, compared with the above, the procuratorial authority becomes the only representative of judicial separation and balance." [4] According to the law requirements and judicial practice, the legal supervision of the people's procuratorate is mainly the legal supervision on litigation, namely the people procuratorate supervises whether the acts of relative authorities and personnel legal or not by participating in the criminal, civil, and administrative litigations. As the plaintiff of administrative public interest, the procuratorial authority will surely better exert its function in legal supervision and preventing abuse of administrative rights

Secondly, as the legal supervisory authority, the procuratorial authority executes procuratorial rights on behalf of the state and is responsible for maintaining correct implementation of law and maintaining social justice. This makes the procuratorial authority the most qualified representative of public interest. "The procuratorial authority has been deemed as the highest representative of legal order and the maintainer of public interest in western countries... A lot of countries have established mature administrative public interest litigation system, in which, the chief procurator plays an important role as the spokesman of public interest." [5] Though there's no clear requirement identifying the people's procuratorial authority as the plaintiff subject of civil public interest cases of environment pollution and harm to numerous consumers' legal rights and interests, it is commonly aware in judicial practical and theoretical field that, the people's procuratorial authority shall be the subject plaintiff. Likewise, for cases concerning illegal administrative act that harms the public interests, such as state-owned assets loss, illegal acts in public construction, and act harmful for environment, the procuratorial authority can also prosecute to the court on behalf of the state to hold the administrative authority legally for its illegal acts or dereliction of duty.

However, it must be noted that, the procuratorial authority cannot prosecute administrative public interest litigation unless all other legal supervisory modes become 
invalid. It shall be the final wall of justice in seeking for remedy. According to the draft proposal of Professor Ma Huaide on the plaintiff qualification of administrative public interest, "in case that the people's procuratorate considers the administrative act infringes upon national interest or social public interest, it may propose the legal suggestion or opinion to require the administrative authorities to rectify. And the administrative authorities shall rectify or reply in written form within one month. For those fail to rectify or replay, or refuse rectifying within required period, the people's procuratorate may prosecute the administrative public interest litigation." When the procuratorial authorities find that the administrative act has or may damage the public interest, it shall propose judicial suggestion, and consider to settle via litigation if the administrative authorities fail to or refuse rectifying.

\section{B. The Social Group Shall Have the Right to Enjoy the Plaintiff Qualification in Administrative Interest Litigation}

The social group is the output of human society that develops to certain stage. It is the interest group composed by certain people based on certain rules. [6]With the modern society development, the social division of labor gets more and more specific, and the social interest also develops in diversified way. Therefore, the government can hardly take care of interests of all parties during its management process on social life. Participation of social group in management on national political life and affairs can effectively maintain the legal rights concerning members of the social group and the masses. The plaintiff qualification endowed to social group of China can help to realize protection of public interest through judicial channel.

Firstly, the social group is a kind of nonprofit social group that is composed by citizens voluntarily in order to realize the common wills of the members and engage in activities according to their regulations. It represents the common interest that the not-fixed majority enjoys in certain field. Though such interest cannot represent the common interest of the whole society, it still belongs to the public interest, especially the interest represented by the commonweal social group. For example, the consumers' association performs social supervision on the commodities and services to protect the legal rights of the massive consumers. The environmental protection association protects the rights of the citizens of the whole nation or a certain region on the environment. According to the nature and tenet of the social group, whenever the interest within its scope is infringed by administrative authority, it shall have more sufficient initiative to protect these interests. Therefore, the social group becomes the positive promoter of public interest litigation. The plaintiff qualification endowed to social group can help to realize protection of group interest and public interest through judicial remedy, and shoulder the social responsibility.

Secondly, most social groups are well organized and professional, and always pay more attention on the issues within their specific fields than other subjects. For example, the environment organization may be aware of the existence of illegal infringement due to its focus on environment pollution and damage problems, thus to take timely measures. Besides, the members of the social group are usually the elites of a certain region, owning professional knowledge and skills, so that they could have more advantages in processing complicated cases like the administrative public interest litigation. Compared with the common people who lack of time and capability, which is the reason causing the failure of even an initiated litigation, the social groups have guarantee of fund and personnel, thus to keep smooth proceedings of the litigation and protect public interest better.

Finally, the plaintiff qualification endowed to social group can effectively reduce the litigation burden of the procuratorial authority. The People's Procuratorates of the People's Republic of China, besides engaging in criminal prosecution on behalf of the nation, is also responsible for the inspection and supervision of the civil and administrative cases. The plaintiff qualification endowed to social group for administrative public interest litigation can greatly reduce the cases for the procuratorates in this aspect, and thus save the judicial sources for the state.

However, the endowing of plaintiff qualification to social groups in administrative public interest litigation shall also note several problems. The firstly, whenever the social group finds administrative infringement on public interest, it shall propose rectification suggestion to the administrative authority, or reflect to the managing authority. And if both the above fail, it may conduct the administrative public interest litigation; secondly, the public interest represented by the social group is limited. It can only represent the interest of a certain field or industry. And therefore, the interest scope for conducting litigation shall be restricted by law. In order to prevent random prosecutions, the scope of Chinese groups for conducting administrative public interest litigation shall be restricted. The social group can only conduct litigation for the public interest infringement closely relating to its initiating tenet and managing affairs. For the public interest damage having no relation with certain fields of the group, considering from the angle of interest relevance and not-matched profession, the social group shall not participate in the litigation as plaintiff identity.

\section{The Individual Citizen Shall Have the Right to Enjoy the Plaintiff Qualification in Administrative Interest Litigation}

Besides the procuratorial authority and social group, the plaintiff qualification recognition of individual citizen in administrative public interest litigation attracts great attention and is debated. In the judicial practice of China, the attempts of individual to conduct civil or administrative public interest litigation are often frustrated. Based on the consideration of preventing random prosecutions and respecting to administrative power, the Civil Procedure Law still has no breakthrough in aspect of restriction to individual citizen conducting civil public interest litigation.

Viewing from the relation between the individual interest of independent citizen and the public interest as an integrity, the individual citizen interest is not conflict to the public 
interest, and both of the above even have unity relation under certain conditions. [7]The integrity of public interest is not simply adding of all independent individual interests, or new interest having no relation with individual interest. It can be deemed as re-combination of non-fixed majority individual interests in social collectivity. When the public interest is damaged, it may possibly affect the individual interest of the citizen. If such bad influence comes from administrative act, the individual citizen shall be endowed with the qualification for conducting litigation to protect the public interest. Administrative public interest litigation conducted by individual citizen could have wide influence on the society, promote the public's focus on public interest and the consciousness to protect legal rights, thus to better protect the public interest.

Certainly, if any citizen could conduct administrative public interest litigation to the court for any affair, the consequences would surely unacceptable. Therefore, the plaintiff qualification endowed to the citizen for administrative public interest litigation must have certain restriction. This is mainly reflected in the stake of the litigation subject and the case. "No direct stake in law" doesn't mean there is no relation.

\section{Priority of Subject Plaintiff Qualification in Administrative Public Interest Litigations in China}

In order to prevent confusion that may occur after conducting administrative litigation at the time when the diversified subjects are maintaining the public interests, based on the establishment of plaintiff qualification of procuratorial authority, social group, and individual citizen in administrative public interest litigation, it shall distinguish the priority of different subjects in conducting litigation as plaintiff. The procuratorial authority shall have the top priority while the social group and individual citizen shall be deemed as supplementation.

\section{CONCLUSION}

With the development of human society, the relation between human and social collectivity gets closer and closer. The overall development of individuals can only be guaranteed by the integrity prosperity and stability of the society. As the society manager, the government should have exerted the power in principle of maximizing social interest. But in practical life, phenomenon that the administrative authorities breach laws and damage public interest happens frequently. In order to protect the public interest and supervise the executive power, the feasible way, which also meets the modern law governance spirits, is to endow rights of conducting judicial inspection for acts of administrative subject harming public interest. In another word, the plaintiff subject qualification in administrative public interest litigation shall be established in laws.

Study on administrative public interest litigation system of China is still in exploration stage. Several problems, including the plaintiff qualification, still need continuous study and discussion. This would surely be a long process with numerous hardships. It is hoped that, the discussion in this paper could initiate more learners to engage in deep research of the plaintiff qualification system of administrative litigation in China.

\section{REFERENCES}

[1] Wang Mingyan, Administrative Law of the United States, China Legal Publishing House, 1995,617

[2] Montesquieu, Translated by Zhang Yanshen, The Spirit of the Laws, The Commercial Press, 1961,154

[3] Qi Shujie, Zheng Xianyu, Difficulties and Outlets of Chinese Public Interest Litigation, Justice of China, Edition 11

[4] Feng Yong, On the Plaintiff Qualification of Procuratorial Authority in Administrative Public Interest Litigation --- From the Angle of Feasibility and Rule Design, Practice Based, 2008, 11

[5] Tian Kai, On Administrative Public Prosecution, China Procuratorate Press, 2009,91

[6] Wang Yan, On Future of Administrative Public Interest Litigation System, Legal Forum, 2002.5

[7] Shen Fujun, On Knowledge and Development of the Plaintiff Qualification System of Administrative Litigation in China, ECUPL Journal, 2014. 